\title{
PERSEPSI GAY TERHADAP PENYEBAB HOMOSEKSUAL
}

\author{
Nanang Khosim Azhari ${ }^{1}$, Herni Susanti ${ }^{2}$, Ice Yulia Susanti ${ }^{2}$ \\ ${ }^{1}$ Akper Kesdam IV / Diponegoro, Semarang, Indonesia \\ ${ }^{2}$ Departemen Keperawatan Jiwa, Fakultas Ilmu Keperawatan Universitas Indonesia \\ nanang.jiwaku@gmail.com
}

\begin{abstract}
ABSTRAK
Orientasi seksual merupakan perasaan ketertarikan secara seksual dan emosional dengan orang lain. Homoseksual merupakan ketertarikan seksual yang terjadi antara sesama jenis kelamin. Hingga saat ini penyebab terjadinya orientasi seksual ini belum dapat dipastikan secara pasti. Prevalensi homoseksual mengalami peningkatan dari tahun ke tahun. Untuk itu peneliti mencoba menggali penyebab homoseksual dari perspektif pelaku homoseksual sendiri. Penelitian ini merupakan penelitian kualitatif dengan pendekatan kualitatif deskriptif. Partisipan dalam penelitian ini berjumlah enam orang. Data yang terkumpul diolah dengan analisa tematik dan diperoleh 1 tema yaitu pengalaman masa lalumenjadipenyebabhomoseksual yang terbentuk dari 2 kategori (menjadi korban pelecehan seksual dan kurang interaksi dengan ayah). Penelitian ini merekomendasikan peran aktif kedua orang tua dalam mendidik anak sejak kecil.
\end{abstract}

Kata kunci : Gay, homoseksual, peran ayah, pengalaman trauma, pelecehan seksual

\section{GAY PERCEPTIONS TO THE CAUSES OF HOMOSEXUALITY}

\begin{abstract}
Sexual orientation is a sexual and emotional attraction feeling with others. Homosexuality is sexual attraction that happens to people with the same sex. Until now, this sexual orientation cause has not been confirmed yet. Homosexuality prevalence has increased from year to year. For this reason, the researchers try to explore the causes of homosexuality by the perspective of homosexuals themselves. This research is a qualitative research with a descriptive qualitative approach. There are six participants in this study. The collected data is processed with thematic analysis and one theme is obtained, past experience is a cause of homosexuality that is formed from two categories (being victims of sexual abuse and lack of interaction with father). This research recommends the active role of both parents in educating children from childhood.
\end{abstract}

Keywords: Gay, homosexual, father's role, trauma experience, sexual abuse

\section{PENDAHULUAN}

Orientasi seksual adalah salah satu bentuk keinginan untuk melakukan kontak seksual dengan orang lain baik dengan sesama atau dengan lawan jenis (Igartu, dkk, 2009). Orintasi seksual merupakan jenis kelamin yang secara privasi menjadi target ketertarikan seksual (Stuart, 2013). Dapat disimpulkan bahwa orientasi seksual merupakan perasaan ketertarikan secara seksual dan emosional kepada orang lain, baik perempuan atau lakilaki. Orientasi seksual terbagi menjadi tiga secara umum, yaitubiseksual, homoseksual dan heteroseksual, namunadatambahansatu yang masihasing di masyarakatyaituaseksual (Sinyo, 2014).
Homoseksualmerupakanketertarikanseksual yang terjadi pada jeniskelamin yang sama. Kebalikan dari homoseksual adalah heteroseksual (ketertarikan kepada jenis kelamin yang berbeda) (Fajriani, 2013; Kamus Besar Bahasa Indonesia, 2018). Heteroseksual merupakan orientasi seksual yang terbanyak di masyarakat umum saat ini (Stuart, 2013). Sedangkan biseksual adalah ketertarikan seksual baik dengan jenis kelamin yang sama atau berbeda (Sadarjoen, 2005). Tidaksemua negara masyarakatnya menerima perbedaan orientasi seksual tersebut, hal ini dikarenakan sosial budaya yang berbeda dan norma yang berbeda tiap negara.

Data yang akurat mengenai jumlah homoseksual yang ada di dunia hingga saat ini 
belum ada jumlahnya secara pasti. Diperkirakan sekitar $10 \%$ dari penduduk lakilaki adalah gay (Kinsey, dalam Santrock, 2003). Data dari Kementrian Kesehatan Republik Indonesia, homoseksual dimasukkan kedalam estimasi dan proyeksi jumlah infeksi HIV (Human Immunodeficiency Virus)tahun 2011 - 2016, dimana dalam proyeksi tersebut jumlah gay mengalami peningkatan setiap tahunnya. Kemenkes RI memprediksikan pada tahun 2011 ada sebanyak 14.532 orang gay kemudian meningkat menjadi 16.883 orang, tahun berikutnya menjadi 19.449 orang dan tahun 2016 menjadi 28.640 orang. Maka dalam tiap tahun kemungkinan ada peningkatan gay yang terinfeksi HIV sebanyak 15\% dari jumlah awal pada tahun 2011. Begitu juga dengan jumlah Orang Dengan HIV AIDS (ODHA) yang orinetasi seksual sesame jenis mengalami peningkatan tiap tahun, dimana pada tahun 2016 ini terdapat sebanyak 153.771 orang. Data ini masih terbatas hanya kaum gay saja belum untuk lesbian dan biseksual.

Sekitar 1.095.970 jiwa di Indonesia menyatakan bahwa dirinya merupakan homosksual (Handayani, 2013). Hasil survey dari Yayasan Pelangi Kasih Nusantara (YPKN) menunjukan bahwa jumlah homosksual di Jakarta antara 4000 hingga 5000 orang dan di Jawa Timur jumlahnya sekitar 5 kali dari jumlah di Jakarta. Hal ini belum termasuk kota besar lainnya (Anggreini, 2014). Oetomo (2001) selaku prersiden gay, mengatakan bahwa jumlah homoseksual di Indonesia sekitar 1\% dari penduduk Indonesia. Kaum homoseksual disini menjadi kaum yang minoritas karena jumlah mereka yang sedikit serta sosial spiritual masyarakat Indonesia tidak menerima keberadaan mereka.

Menurut sebagian orang homoseksual dikatakan sebagai suatu bentuk perilaku seksual yang menyimpang, ditandai dengan adanya ketertarikan perasaan secara emosional dan atau secara erotic terhadap sesame jenis, dan bahkan ada yang sampai melakukan hubungan seks dengan mulut (oral seks) atau dubur (sodomi, anal seks) (Hawari, 2009). Hal ini diperkuat oleh penelitian yang dilakukan oleh Ott (2010) yang menyatakan bahwa homoseksual dan biseksual mengarah keorientasi seksual yang tidak sehat. Homoseksual terbagi menjadi dua jenis, yaitu ketertarikan sesame laki-laki atau disebut dengan gay dan ketertarikan terhadap sesame perempuan yang biasa disebut lesbian. Tidak semua masyarakat dapat menerima orientasi seksualtersebut, dikarena sosial budaya dan norma yang ada pada tiap masyarakat berbeda. Pembentukan orientasi seksual seseorang dapat ditentukan oleh kombinasi beberapa faktor, seperti genetik, kognitif, hormonal serta lingkungan (McWhirter, Reinisch, \& Snader, 1989; SaVin - Williams \& Rodriguez, 1993; Whitman, Diamond \& Martin, 1993, dalam Santrock, 2003). Penyebab lain terjadinya perilaku homoseksual dibagi dalam dua pendekatan. Pendekatan yang pertama yaitu pendekatan fisiologis dimana hormonhormonberadadalamkondisi yang tidak homeostatis, namun hal ini hany aberlaku pada kasus-kasus tertentu serta belum ada penelitian yang pasti hormone tersebut sebagai faktor munculnya homoseksualitas. Pendekatan kedua melalui pendekatan psikologi, yang bertumpu pada pengalaman individu terkait homoseksual seperti, pengalaman homoseksual usia dini, identifikasi silang, ketakutan akanp engebirian, dan faktor psikologis lain (i.e, takut menikah antara lain karena orangtua selalu bertengkar, takut memikul tanggungjawab) (Yustinus, 2006).

Pendapat lain menyebutkan bahwa homoseksual terkait dengan genetik. Pria yang homoseksual cenderung memiliki saudara yang homoseksual dari keturuanan ibunya. Pada sebuah penelitian terhadap 40 keluarga yang terdapat dua bersaudara gay mengungkapkan adanya korelasi antara orientasi homoseksual dan warisan penanda polimorfik pada kromosom X sekitar 64\% (Hammer,D.H., dkk, 1993, dalam Carroll, 2012).Melalui fenomena di atas, dimana jumlah homoseksual yang semakin meningkat dan penyebab homoseksual yang belum diketahui secara pasti menggugah minat peneliti untuk melakukan studi deskriptif mengenai penyebab homoseksual. Penelitian ini mencoba menggali pendapat dari pelaku homoseksual mengenai penyebab orinetasi seksual mereka yang berbeda dari masyarakat pada umumnya.

\section{METODE}

Penelitian ini merupakan penelitian kualitatif dengan pendekatan deskriptif kualitatif. 
Pemilihan partisipan berdasarkan purposive sampling dan pengambilang sampel dengan cara snowball. Partisipan dalam penelitian ini adalah seseorang yang telah menyatakan dirinya homoseksual. Partisipan yang diambil sebanyak 6 orang dengan pertimbangan data yang diperoleh sudah jenuh (tidak ditemukan data baru). Data yang sudah terkumpul diolah dengan Analisa tematik (Braun \& Clarke, 2006). Sebelum dianalisa, data terlebih dahulu divalidasi kembali oleh partisipan, dan di review oleh orang lain agar data yang diperoleh dapat dipertanggungjawabkan.

\section{HASIL}

\section{KarakterisitikPartisipan}

Partisipan dalam penelitian ini mempunyai usia antara 20 - 32 tahun, dengan Pendidikan minimal SMA dan yang tertinggi Pasca sarjana. Profesi partisipan beraneka macam, 2 sebagai karyawan swasta, 2 sebagai pegawai negeri sipil, 1 sebagai guru dan 1 sebagai perawat. Kesemua partisipan berjenis kelamin laki - laki dan beragama islam yang tinggal di Kota Jakarta, Bandung, Makasar dan Lampung.

\section{Analisa Tematik}

Pada penelitianini teridentifikasi 1 temaya itu pengalaman masa lalu menjadi penyebab homoseksual. Tema tersebut terbentuk dari 2 kategori yaitu :yang pertama pengalaman menjadi korban pelecehan seksual seperti partisipan menyatakan diajak ke kamar, digituin (i.e, diraba - raba, dipeluk - peluk) dan diminta melakukan aktivitas seksual. Kategori kedua yaitu partisipan merasa jarang atau kurang berkomunikasi dengan orangtua khususnya ayah, hal ini dikarena ayah yang selalusibuk bekerja, pulang malam, merantau atau kerja pagi hinggapetang.

Sebanyak 3 dari 6 partisipan menyatakan pernah mengalami pelecehan seksual yang secara tidak langsung dapat berdampak pada psikologis partisipan. Partisipan kedua menceritakan bahwa dia pada awalnya berkenalan dengan seseorang yang tinggal tidak jauh dari tempat kosnya. Setelah perkenalan tersebut orang itu sering main di tempat kos partisipan. Sampai pada suatu hari orang tersebut meminta partisipan untuk menemani ke rumahnya dan tidur disana. Kemudian pada malamnya partisipan mengalami pelecehan seksual, setelah kejadian tersebut partisipan merasa frustasi. Hal ini diungkap oleh partisipan sebagai berikut :

"Terus malam itu saya ya dipeluk dicium tapi nggak berhubungan kayak suami istri gitu, sampai mastrubasi. Terus paginya saya terus lari... (P6)

Saya waktu kecil ada pengalaman mengalami kekerasan seksual, dari sodara saya paman saya gitu ya, waktu kecil usia 8 tahun. Jadi sering diajak (ditidurin, disodomi), tapi saya belum tau arti dari kejadianitu (P4)"

Pada pernyataan selanjutnya partisipan kedua mengatakan rasa penyesalan mengapa harus dia yang mengalami pelecehan seksual. Hal serupa juga dirasakan oleh partisipan ketiga, dimana setelah dia mengalami pelecehan seksual partisipan lebih cenderung menutup diri atau melamun. Pelecehan seksual yang dialami oleh partisipan ketiga dan keenam terjadi ketika masih Sekolah Dasar (SD), dan terjadi berulangkali. Namun yang menarik adalah partisipan kedua hanya sekali mengalami pelecehan seksual, dan terjadi saat masih Sekolah Menengah Atas (SMA).

Kurangnya interaksi dengan orang tua khususnya ayah menjadi salah satu latar belakang partisipan menjadi homoseksual. Partisipan kedua mengatakan bahwa ayahnya seorang pedagang sehingga interaksi dengan ayah hanya seperlunya saja. Partisipan tersebut menjadi lebih dekat dengan ibu, dan jika ada keperluan partisipan meminta kepada ibunya untuk disampaikan ke ayah. Partisipan keempat juga jarang berinteraksi dengan ayah. Partisipan menganggap hal tersebut akibat pola didik dari kakek, yang mengakibatkan ayah jarang berinteraksi dengan anak. Hal tersebut juga mengakibatkan partisipan keempat lebih suka dengan pasangan sesama jenis yang lebih tua, karena lebih dapat memberikan perhatian dibandingkan dengan yang seusianya. Partisipan keenam juga mengatakan bahwa ayah kerja dari pagi sampai sore, begitu juga dengan partisipan 4 yang menyatakan bahwa dia dirawat oleh kakek neneknya dikarena orang tua merantau. Berikut adalah pernyataan-pernyataan yang menggambarkan tentang kurangnya interaksi dengan orang tua khususnya ayah: 
"Ayah saya tukang pedagang, jadi kalo pulang malam. Kalo bertemu ya kalo lagi pas nggak berdagang. (P6)

....ya semua emang nggak terlalu akrab dengan ayah namun mungkin saya yang paling tidak akrab dengan ayah, nggak tau mungkin cara asuh orang tua eh ayah maksudnya gitu (P4)"

Hal ini diungkapkan hampir oleh semua partisipan yang mempunyai pengalaman kurang interaksi dengan orang tua terutama dengan ayah.Pengalaman menjadi korban pelecehan seksual yang dialami partisipan menjadikan partisipan menarik diri, baik dari lingkungan maupaun teman laki-laki. Kemudian interaksi yang kurang baik dengan orang tua khususnya ayah menyebabkan partisipan merasa kehilangan sesosok orang yang mampu mengayomi. Hal tersebutlah yang mengakibatkan partisipan mencari seseorang yang mampu memberikan rasa aman. Sehingga baik pengalaman mengalami pelecehan seksual atau interaksi yang kurang baik dengan orang tua khususnya ayah dapat mengakibatkan partisipan memiliki orientasi seksual sesama jenis.

\section{PEMBAHASAN}

Homoseksual merupakan suatu kondisi dimana adanya ketertarikan terhadap sesama jenis(Stuart, 2013). Hingga saat ini alasan yang melatabelakangi terbentuknya orientasi ini masih banyak diperdebatkan oleh para ahli. Tidak adanya single faktor yang menjadikan seseorang homoseksual, melainkan dapat disebabkan karena banyak faktor seperti yang dikemukakan oleh Money (dalam Feldmen, 1990).Penyebab terjadinya homoseksual ada beberapa hal (Feldmen, 1990). Beberapa pendekatan seperti pendekatan biologi menyatakan faktor genetik atau hormonal mempengaruhi perkembangan orientasi seksual seseorang.

Psikoanalis lain menyatakan bahwa kondisi atau pengaruh ibu yang dominan dan terlalu melindungi sedangkanayah cenderung pasif (Breber dalam Feldmen, 1990). Penyebab lain dari homoseksualitas seseorang yaitu karena faktor pembelajaran (Master dan Johnston dalam Feldmen, 1990). Hal tersebut mempunyai arti bahwa orientasi seksual seseorang dapat dipelajari sebagai akibat adanya reward dan punishment yang diterima.Pada penelitian ini hal - hal yang melatar belakangi terbentuknya homoseksual terfokus pada dua hal yaitu : Pertama pengalaman menjadi korban pelecehan seksual. Sebagaimana penelitian yang dilakukan oleh Polusny \& Victoria (1995), mengenai korelasi jangka panjang terhadap pelecehan seksual pada anak.

Anak yang mengalami pelecehan seksual menyebabkan berbagai macam dampak seperti hubungan interpersonal dan sosial yang kurang baik, ketidakpuasan seksual, disfungsi dan ketidakcocokan seksual yang berlebihan termasuk perilaku seksual beresiko tinggi dan lain - lain (Noviana, 2015). Pada penelitian ini partisipan kedua, ketiga dan keenam pernah mengalami pelecehan seksual. Partisipan kedua dan ketiga melaporkan bahwa setelah mengalami pelecehan seksual tersebut dirinya juga mengalami depresi dan menjadi lebih menutup diri. Khususnya partisipan ketiga yang menyatakan dia menjadi menyendiri dan sering melamun setelah kejadian tersebut. Kemudian partisipan kedua merasa frustasi dan lebih menutup diri setelah terjadinya pelecehan seksual tersebut, menghindar dari laki - laki dan menyangkal bahwa dirinya telah mengalami pelecehan seksual tersebut.

Pelecehan seksual pada partisipan ketiga dan keempat terjadi pada masa sekolah yaitu saat Sekolah Dasar (SD) antara usia 6 hingga 7 tahun. Tugas perkembangan pada masa sekolah menurut Robert J. Havighurst salah satunya adalah belajar peranan jenis kelamin, hal ini menjadi beresiko tinggi terjadi penyimpangan apabila pada masa sekolah ini anak mendapat pelecehan seksual terhadap sesama jenis kelamin. Terlebih lagi tiga partisipan yang mengalami pelecehan seksual tersebut menyembunyikan hal tersebut. Sehingga dalam proses pembelajaran peranan jenis kelamin, dapat mengalami gangguan seperti yang disampaikan oleh Polusny \& Victoria (1995). Selain itu dampak jangka panjang korban pelecehan seksual yaitu korban berpotensi untuk melakukan hal yang serupa dikemudian hari (Weber \& Smith, 2010).

Dapat disimpulkan bahwa korban pelecehan seksual pada masa kecil memiliki potensi 
untuk menjadi pelaku pelcehan seksual. Maka apabila pelecehan seksual itu dilakukan oleh sesama jenis, berpotensi juga korban akan menjadi pelaku pelecehan seksual sesama jenis juga dan hal tersebut mungkin juga dapat melatar belakangi terbentuknya orientasi seksual sesama jenis. Hal ini diperkuat oleh penelitian yang dilakukan oleh Jinich (1998). Dimana pada penelitian tersebut mengindikasikan bahwa biseksual dan gay yang tinggal di Portland dan Tucson mempunyai riwayat pelecehan seksual pada masa kanak - kanaknya oleh orang yang lebih dewasa. Selanjutnya penelitian yang dilakukan oleh Mu'allaf (2014), menghasilkan bahwa kasus pelecehan seksual pada anak dapat menjadi salah satu faktor pembentuk perilaku seksual yang abnormal.

Kategori kedua yaitu kurangnya interaksi dengan ayah menjadi salah satu hal yang melatar belakangi partisipan menjadi homoseksual. Keluarga menjadi salah satu faktor yang menyebabkan seseorang menjadi homoseksual (Elizabth, 2010). Kurangnya figur seorang ayah, sehingga mencari perhatian keteman laki - laki sejenis untuk menggantikan ayah dinyatakan oleh partisipan keempat. Partisipan mencari teman laki - laki yang lebih tua karena merasa ada yang mengayomi. Pendapat ini sesuai dengan Mardiyah (2017) yang menyatakan bahwa apabila peran ibu lebih dominan terhadap ayah atau tidak adanya figur seorang ayah, maka baik secara fisik maupun psikologis terjadi proses indentifikasi yang salah. anak laki laki akan lebih condong meniru ibu.

Jika ditelusuri lebih dalam lima dari enam partisipan menyatakan bahwa dulu waktu kecil mempunyai sifat yang feminim, dan ada yang menyatakan lebih suka bermain dengan permainan perempuan seperti boneka, membaca majalah wanita dan bermain rumah rumahan. Kurangnya kasih sayang atau pemenuhan kebutuhan afeksi dalam keluarga juga menyebabkan seseorang menjadi homoseksual (Efa, 2015). Seperti yang dialami oleh partisipan ketiga, dimana sejak kecil dia diasuh oleh kakek dan nenek partisipan, karena orang tua merantau. Padahal pola asuh orang tua berhubungan dengan tingkat homoseksual seseorang, hal ini sesuai dengan penelitian yang dilakukan oleh Pontoh (2015). Pada penelitian tersebut dijelaskan bahwa terdapat hubungan yang bermakna antara pola asuh dengan tingkat homoseksual.

Pola asuh yang dimaksud adalah pola asuh indifferent. Orang tua dengan pola asuh tersebut memiliki kontrol tingkah laku yang rendah dan membiarkan anak melakukan hal semaunya, sehingga anak tidak takut dalam mengambil keputusan penting untuk dirinya sendiri termasuk dalam hal menjalin hubungan dengan sesama jenisnya (Hurlock, 2013).Kemudian penelitian yang dilakukan oleh Indryawati (2006) mengenai Pengaruh Pola Asuh Orang Tua Terhadap Perilaku Homoseksual menyebutkan bahwa pola asuh orang tua khususnya ayah sangat berperan dalam pembentukan perilaku homoseksual.

\section{SIMPULAN DAN SARAN \\ Simpulan}

Berdasarkan hasilpenelitian dapat disimpulkan bahwa penyebab terjadinya homoseksual karena dua hal yaitu pengalaman menjadi korban pelecehan seksual dan kurangnya interaksi dengan ayah. Peranan orang tua sangat penting bagi perkembangan anak, karena orang tua merupakan tempat proses pembelajaran awal seorang anak - anak. Begitu juga dengan pelecehan seksual yang terjadi pada partisipan seharusnya dapat dicegah jika orang tua memantau dengan baik aktivitas anak dan memberikan pemahaman yang baik kepada anak terkait seksualitas. Anak yang tidak dekat dengan orang tua mengakibatkan ia tidak mau bercerita mengenai pengalaman baru yang ia dapatkan. Akibatnya anak belajar memahami sendiri pengalaman yang ia alami, hal ini tentunya sangat berisiko apabila terjadi salah pemahaman. Figur seorang ayah juga diperlukan dalam proses pembentukan jati diri. Seorang anak laki - laki yang kehilangan figur seorang ayah, dapat mengakibatkan ia mengadopsi figur ibu dan sebaliknya.

\section{Saran}

Peran aktif kedua orang tua dalam mendidik anak sejak kecil sangatlah diperlukan salah satunya untuk mencegah terjadinya homoseksual.

\section{DAFTAR PUSTAKA}


Stuart, G.W. (2013). Principles and Practice of Psychiatric Nursing. Missouri: Elsevier Mosby.

Sinyo.(2014). Anakkubertanyatentang LGBT. Jakarta: Gramedia.

Fajriani, GAR. 2013. Gambaran social well being pada homoseksualdewasa muda yang melakukan coming out. Bandung. Universitas Pendidikan Indonesia

Sadarjoen, S S. (2005). Bunga Rampai Kasus Psiko-Seksual (edisipertama). Bandung: PT RefikaAditama.

Santrock, John., W. (2003). Adolescence :perkembanganremaja (edisikeenam). (Penerj.Shinto B. Adelar, Sherly Saragih; Ed. Wisnu C, Kristiaji, YatiSumiharti).Jakarta :Erlangga.

Handayani, S (2013). Konsep Dan PrestasiDiri Gay Pada KelompokKegiatanSeni Di Kota Padang :UniversitasAndalas. Padang

Anggreini, Sekar. (2014). Kesejahteraan subjektif pria dengan orientasi seksual sejenis. Bandung: Universitas Pendidikan Indonesia.

Oetomo, D. (2001). Member isuara pada yang Bisu. Yogyakarta: Galang Press.

Hawari, D. (2009). Pendekatanpsikoreligi pada homoseksual. Jakarta:BalaiPenerbit FKUI.

Ott, M.A. (2010). Examining the development and sexual behavior of adolescent males.Journal of Adolescent Health, 46, S3-S11.

Yustinus, Semiun. (2006). Kesehatan Mental 2. Yogyakarta: Kanisius.

Carroll, L. J. (2012). Sexuality Now: Embracing Diversity (4th ed.). USA: Belmont: Thomson Learning Inc.

Braun \& Clarke. (2006). Using Thematic Analysis in Psychology. Qualitative Research in Pshycology, 3 (2). Pp 77101. ISSN 1478-0887
Feldmen, R. S. (1990). Understanding Psychology, Second Edition. New York: McGraw-Hill Publishing Company.

Polusny, Melissa. A., \& Victoria, M. Folle. (1995). Long-term correlates of child sexual abuse: Theory and review of the empirical literature. USA: Applied $\&$ Preventive Psychology 4:143-166.

Noviana, I. (2015). Kekerasan seksual terhadap anak: dampak dan penanganannya. Jakarta: Pusat Penelitian dan Pengembangan Kesejahteraan Sosial, Kementrian Sosial RI.

Weber, Mark Reese., Smith, Dana M.(2010). Outcomes of Child Sexual Abuse as Predictors of laters Sexual Victimization.Journal of International Violence.(Online). 26 (9): 1899-1905.

Jinich, S., et al. (1998).Childhood sexual abuse and HIV risk-taking behavior among gay and bisexual men. AIDS and Behavior, 2(1), 41-51.

Efa, Yuliwati. (2015). Identifikasi Orientasi Homoseksual Pada Laki-laki (gay) BerdasarkanTeori WHO.Skripsi thesis, UniversitasAirlangga.

Pontoh, Maria.M., dkk. (2015). Hubungan pola asuh orang tuadengan tingkat homoseksual pada komunitasgayx di Manado.Manado :JurnalBiomedik (eBm), Volume 3

Mardiyah, Isyatul. (2017). Peran ayah dalam menanamkan sikap self acceptance dalam rangka mencegah perilaku homoseksual pada anak. Pontianak: Institusi Agama Islam Negeri (IAIN) Pontianak.

Hurlock, E B.(2013). Child growth and development. USA: Literary Licensing; p.54

Indryawati, Rini. (2006). Pengaruh pola asuh orangtu aterhadap perilaku homoseksual.J akarta:Universitas Gunadarma. 